\title{
Translation Assisted Language Learning:
}

\author{
Translation as A Media in Language Teaching
}

\author{
Irfan Dwi Yulianto \\ Yogyakarta State University \\ Yogyakarta, Indonesia \\ irfandwi46@gmail.com
}

\begin{abstract}
Translation in language teaching seemingly refers to Grammar Translation Method. In fact, nowadays it is different. Back than in history, translation in language had been abandoned since it was considered as deferral of language improvement. Modern language teaching proposes direct method, communicative approach, and many other methods and strategies in enhancing language competence of the students. On the contrary, as EFL students, they tend to translate the text to understand what the text is trying to explain. Hence, this paper reveal the bright side of translation in language teaching. Translation in language teaching assists the students to understand the meaning of the text. As it is commonly known that the purpose of language is to communicate between one and another. Translation thus, helps the students to understand the real meaning of the message which is on the written form. Translation moreover can assist the students to acquire a language. Through translation the many aspects of language are learned. Therefore, conducting the translation in language learning will enhance students' language skill as well as an assistance for the teacher to emphasize on certain sector in language teaching.
\end{abstract}

Keywords-translation; language teaching; Translation Assisted Language Learning

\section{INTRODUCTION}

It is such a universal truth that mastering language is everybody's necessity today. Knowing only a language seems not enough as the language advancement has been rapidly moved. English plays a crucial role in both knowledge improvement and communication. People around the world deliver their message through language. The message can be in written or oral form. Somehow, language can be a burden in communication, due to the differences in language. Every language has its own uniqueness. The characteristic of language might be slightly different or even totally different. Thus, language is an arbitrary sign. As we all know that language has many definitions. It can be referred as the tool of communication, as the sign, and system. As a means of communication, language is crucial thing, according to De Saussure in Chaer [1] language plays a role as parole, langue and language. Parole refers to the utterance that is made by the speaker, or writer, langue is an abstract object of language system itself, and language is the most abstract object because of its universality. So language is like phenomenon that assort the sound, culture and meaning.
Furthermore, in order to form a language there must be word, phrase, clause and sentence. Regardless, there are so complex process in the construction of the language itself. It is begun with word building, the process of word building starts from compounding, prefixation, suffixation, conversion, back formation, clipping, blends, acronyms, word manufacture and misformation [2]. Phrase and clause has similar process with the word. According to Chaer [1], to build a comprehensive understanding toward language, there must be a group of word becoming sentence. Thus, a good sentence will properly deliver the message of the writer or the speaker. Other than that, it is certainly a problem when the writer or the speaker wants to deliver a message, but the receiver figures a different referent. Consequently, the goal of communication is missed when the message is not perfectly delivered. To deal with it, the advancement of language teaching and learning promotes many strategies to cope with this issue. Translation in language teaching to assist the learner in understanding the core of certain text in a different language. This paper will try to explain how translation assists the students in learning language as well as in the perspective of language teaching and learning as a media of language teaching.

\section{LANGUAGE TEACHING IN MODERN ERA}

Since the advancement of language, language teaching plays a crucial role in nowadays' education. Language become one of the important things in education. Language is the only way to deliver a message. Language as the mean of communication, language plays an important role to deliver the message properly. Afterwards, terms on language and education emerge such as ESL, EFL, and then ELF. Due to its importance, language is considered as the material to be taught in school. The circumstances foremost in language teaching, can also effect in the academic environment. School has a massive role to develop students' ability. Since the idea of ELF or English as Lingua Franca spread around the world, the international labelled school is also increased, English is not only the introduction, but also the language that mostly used both in written and spoken form. Despite of its usage, English has been the most familiar language for Indonesian students. Notwithstanding, the ability to transfer the meaning into the target language can sometimes be a big problem for the students. Though, English is taught in vary of methods. English sometimes become one of the "specter" in school as a 
second or foreign language. Consequently, the barrier of language often become a burden for knowledge exchange. Thus, methods and strategies to deal with language barrier established then.

Grammar Translation Method came at the first time as method in language teaching, as it was developed by Germany Scholars. In $19^{\text {th }}$ century, this method is abandoned as it is considers as inappropriate language teaching method and also delay language improvement. Thus, it motivated other scholars to promote a method in language teaching. Audio lingual, and communicative approach as the method in language teaching were established then [3], [4]. Grammar Translation Method as the first method established in the world of language teaching dominated for several years. In this method, teaching and learning activities is taught in mother tongue. Vocabulary are given in the form of list, students are passive, the explanation are much longer or considered as teacher centered, and the rule of grammar is highly emphasized [3]. Those characteristics of grammar translation method seemingly out of the line of modern language scholar. It was considered as an ineffective way in language learning. The most reason why Grammar Translation Method was abandoned in language teaching was the delay of second or foreign language improvement.

Language teaching thus developed rapidly in this global era. Language as a means of communication is considered as a significant thing in the development of global communication. Language teaching as it is known as the media on pursuing broad knowledge in nowadays place in an important role. The development of language teaching has been rapidly realized. Those old fashioned language teaching methods are modified to be more effective in the development of language. Translation in Language Teaching (TILT) emerge in this modern language teaching. Despite of being useless and counterproductive, Translation in Language Teaching claims its usefulness toward Language teaching [5]. Translation in language teaching able to stimulate the learner or the real language that they are learning. Nevertheless, translation is perceived in the different point of view of scholars, teachers, as well as linguist. Some of them agree while some other strongly disagree [6].

\section{THE NOTION OF TRANSLATION}

Before going further to translation in language teaching, translation is always associated with a profession and strategy to transfer the meaning of L1 to L2 as it was promoted by Newmark [7]. In fact it is more than a profession in transferring the meaning only. More than that, translation is a purposeful act, Nord (2001) explains that translation is categorized in to two major subdivisions. Translation which focus on Source Text and translation which focus on the Target Text. Many scholars of translation promotes the same thing in the different terminology though, such as Vinay and Darbelnet in Munday [8] promote direct and oblique, direct and indirect by Newmark [7] other than that the point of translation is to find the right point of view of source text to target text. The first subdivision tend to translate the text as the Source text in equivalence without any consideration of the reader, on the contrary, the second one tend to focus on the target text or the target reader. Furthermore translating the text may employ direct or oblique translation and then it is divided again in seven procedures theoretically [8]. Again, theoretically it is divided into seven procedures are, though, students may do not understand those procedures. First, Borrowing, calque and literal translation, as a part of direct translation. In oblique translation there are more complex procedures, such as transposition, modulation, equivalence, and adaptation. In short, translation includes many aspect in term of language.

Additionally, Catford [9, p. 21] classifies some categories of translation in terms of the extents, level and rank of translation. The extents of translation are classified into full and partial translation. In a full translation, every part of the SL text is replaced by the TL text material, while in partial translation; some parts of the SL text are left untranslated. Two categories of the level of translation are total and restricted translation. Both of them have distinctions related to the level of language involved in translation. Total translation is the replacement of the SL grammar and lexis by equivalent TL grammar and lexis with consequential replacement of SL phonology or graphology. Whereas, restricted translation is the replacement of SL textual material by equivalent TL textual material at only one level, that is, translation performs only at the phonological or at the graphological level, or at only one of two levels of grammar and lexis [9, p. 22].

The last but not least, is the rank of translation. The two classification of this categorization are rank-bounded and unbounded translation. It is related to the rank in a grammatical or phonological hierarchy at which translation equivalence is established. An attempt in translation is made always to select TL equivalence at the same rank or one rank and it is usually called rank-bounded. In contrast, if the translation in which equivalence shifts freely up and down the rank scale, it may be termed unbounded translation [9]. Doing those complex procedures will engage the students in mastering language. Nonetheless, students do not realize those procedures while doing the translation because there is no translation study in high school.

In addition, as the purposeful activity, unavoidably, translation involves many disciplines on its process. First of all, psycholinguistics as in the part of language perception and language production. According to Susanto and Yulianto [10] the process of translation includes the sight, then it goes to occipital, wernicke, and motoric nerve so then the product of translation is created after those long process in the brain. People have to read first in the process of translation. After reading the text it goes to occipital, and then processed in wernick. Folder of languages and knowledge are selected and then it is process to motoric nerve to move our hand and 
creating the product of translation. In short, the richest vocabulary we have the better the translation is produced. This arguments completes the argument which was promoted by [7] and [11] who stated that translation process is begun fom Text, and then discovering meaning, re expressing meaning and translation product.. Thus, translation is a purposeful and complex thing which is aimed to achieve the goal of proper communication. A good translation leads to a right communication in the written form.

\section{TRANSLAtion IN THE PERSPECTIVE OF LANGUAGE TEACHING}

Translation is a controversy thing since it has two major controversies in language teaching, whether it is good or need to be avoided in language teaching. Otherwise, [12], [6] state that translation is useful in Language teaching. Translation brings many advantages in learning vocabulary, grammar, also in writing. Furthermore, Translation will also enhance accuracy, flexibility, and clarity between source language and target language, it also a real sample of the use of language as communication means in the real world [5]. Thus, despite its rareness in language teaching, translation in language teaching brings some significances in the development of second or foreign language teaching. The modified translation teaching method bring some advantages to the teacher as well. Teacher can underlined those issues produced by the students in their translational work. This research was applied by Murtisari [12] for university students. Otherwise, there still no study about translation in assisting language learner of High School Students.

On the other hand, in modern perspective, translation has infinite notions. The consideration of language development leads the critical understanding of the reader. Translation goes wide and no longer as faithful as in pre-systemic view [13]. Translation raises in language teaching as an assistant in the area of EFL. Despite its unpopularity, translation is a helpful tool to measure the lack of EFL learners. Teachers of EFL can measure the ability of their students through the identification of error in their students' translational work. It is useful as it is the reassemble of an authentic language for the learner. According to Vermes [14], divided translation in language teaching into two part, it is pedagogical translation and real translation.

To sum up, Tou [15] argues that translation as an interlingual communication act which explains that first language and second or foreign language are a parallel language development which native language is born first. Thus, the distinction among languages is an unavoidable thing. Interestingly, Gadamer in [15] explains that language itself is translation, all communication act is translation as well. Duff in [6] states that translation happens everywhere. Students translate the instruction, students translate the task given in the class in order to understand what the task is. In conclusion all of communication act involves a translation.

So, actually, translation in language teaching is not an oldfashioned teaching method toward language learning. It deals with the goal of language teaching, it is not a way to be a native speaker, or native like, but it is the way to reach a good communication among languages [16], translation in language teaching assist the students to understand the meaning of the text instead of grammatical structure. It is obviously assist the students to learn other language and moreover acquire a second or third language, translation is a means to understand the meaning of certain text [17]. Finally, translation is a useful strategy to cope with language learning. It goes in a complex way which engage the students to understand and acquire the language. The use of translation in language teaching can be a prior activity or as a measurement of language competency. Translation then developed as a media or a help in language teaching. Trough simulant translation teacher can easily identify the error.

\section{CONCLUSION}

Mainly, because of excessive negative opinion toward Grammar Translation Method, this old-fashioned method in language teaching has been abandoned in a modern language teaching. One way or another, translation in language teaching is also considered as non-communicative language teaching strategy in language teaching. It is universally known that translation in language teaching has a close relations to Grammar Translation method. In fact, it is different. Grammar translation method in language teaching focused on the structure of the text, the explanation is done in mother tongue, and it focused on the precise structure instead of the content. In short it is teacher centered learning. On the other hand, translation in language teaching focusses on how the students able to understand the meaning of the text contextually. Thus, translation in language teaching can assist the students in learning other language. Moreover, Translation in Language Teaching can enhance the students in learning vocabulary, grammar, also in writing. Furthermore, Translation will also enhance accuracy, flexibility, and clarity between source language and target language, it also a real sample of the use of language as communication means in the real world.

As the process of translation is not as simple as it seems, translation engages many disciplines. It includes the sight and then goes to occipital and then it is processed in wernick to find the folders of dictions, word, expression and other related thing to produce a good translation. The richest vocabulary we have the better the translation is produced. Thus, Translation in language teaching is a good way in teaching language due to its excess in language use. Other than that, translation will also help the teachers to identify the errors which made by the students. Those errors can be noted and then managed by the teachers.

Translation can be everywhere. Expressing the feeling in language is translation, students translate the instruction given by the teacher, and students translate the text in order to know what the text is trying to say. Thus, all of communication act involves translation. So language teaching and translation has 
a close relationship due to communication purposes in other language.

\section{REFERENCES}

[1] A. Chaer, Linguistik Umum [General Linguistic]. Jakarta: Rhineka Cipta, 2012.

[2] L. Bauer, English Word-Formation. Cambridge: University of Cambridge Press, 1983.

[3] H. D. Brown, Teching By Principles an Interactive Approach to Language Pedagogy. New York: Pearson Education Company, 2001.

[4] J. Harmer, The Practice of English Language Teaching, 3rd ed. Cambridge: Longman, 2003.

[5] A. F. Guera, "The usefulness of Translation In Foreign Language Learning; Students' Atitudes,” Engl. Lang. and Translat. Stud., pp. 153170, 2015.

[6] I. Dagilienè, "Translation as a Method in English Language Learning . Study About Language, 124-131, 2015.

[7] P. Newmark, A Textbook of Translation. New York: Prentience, 1987.

[8] J. Munday, Introducing to Translation Studies. London: Routledge, 2016 .
[9] J. Catford, A Linguistics Theory of Translation. London: Cambridge University Press, 1978.

[10] R. Susanto, and I. D. Yulianto, "Penerjemahan dalam Sudut Pandang Psycolinguistics [Translation in Psycholinguistics Perspective]," National Conference on Corpus Linguistics, 2017.

[11] M. L. Larson, Penerjemahan Berdasakan Makna: Pedoman untuk Pemadanan Antarbahasa [Meaning-based Translation: Guidance for Interlanguage Equalization]. Jakarta: ARCAN, 1989.

[12] E. T. “Translation Skill in Language Learning / Teaching: Learner's Point of View,” Stud. About Lang., pp. 102-115, 2016.

[13] G. Medadian and D. N. Mahabadi, “A Summative Translation Quality Assessment Model for Undergraduate Transalation Students: Objectivity VS Managebility,” Res. J. Stud. About Lang., pp. 40-54, 2015.

[14] A. Vermes, "Translation in Foreign Language Teaching: A Brief Overview of Pros and Cons,” Eger J. of Engl. Stud. X, pp. 83-93, 2010.

[15] A. B. Tou, “The Translatics of Translation,” J. of Moder. Lang., pp. 14 40, 2008.

[16] W. Juanggo, "The Concept of L2 User and the goals of Second Language Learning,” Jurn. Stud. Komun. (Indonesian J. of Commun. Stud.), pp. 101-115, 2017.

[17] K. Izuni, “Translation-aided Approach in Second Acquisition,” JALT j., pp. 225-237, 1995. 